\title{
Contribution of algal sinking and zooplankton grazing to downward flux in the Lazarev Sea (Southern Ocean) during the onset of phytoplankton bloom: a lagrangian study
}

\author{
E. A. Pakhomov ${ }^{1,2, *}$, P. W. Froneman ${ }^{1}$, P. Wassmann ${ }^{3}$, T. Ratkova ${ }^{4}$, E. Arashkevich ${ }^{4}$ \\ ${ }^{1}$ Southern Ocean Group, Department of Zoology and Entomology, Rhodes University, PO Box 94, Grahamstown 6140, \\ South Africa \\ ${ }^{2}$ Department of Zoology, University of Fort Hare, Private Bag X1314, Alice 5700, South Africa \\ ${ }^{3}$ Norwegian College of Fishery Science, University of Tromsø, 9037 Tromsø, Norway \\ ${ }^{4}$ P. P. Shirshov Institute of Oceanology, Russian Academy of Sciences, Nakhimovsky Avenue 36, 117541 Moscow, Russia
}

\begin{abstract}
Hydrography, chlorophyll $a$, phytoplankton and zooplankton dynamics and the vertical flux of particulate organic carbon (POC) and pigments in the upper $200 \mathrm{~m}$ were investigated for 12 consecutive days during a drogue study conducted in the open waters of the ice-edge zone of the Lazarev Sea during the austral summer (December/January) 1994/95. Results of the study indicate that during the experiment, primary production, although variable, increased from $\sim 300$ to $\sim 800 \mathrm{mg} \mathrm{C} \mathrm{m}^{-2} \mathrm{~d}^{-1}$. This increase could likely be related to development of a shallow pycnocline. Analysis of sediment trap data showed that the vertical carbon flux resulting from sedimentation and grazing activity was greatest in the upper water column $(<80 \mathrm{~m})$. The importance of grazers to total POC flux was highest at the beginning and the end of the investigation and accounted for up to $15 \%$ of total carbon flux. The contribution of grazers to vertical flux was negligible $(<2 \%)$ during the intermediate part of the Southern Ocean Drogue study. Lower contribution of grazers to sedimentation of POC at depth can likely be related to community composition of zooplankton. Sedimentation of phytoplankton cells from the upper water column increased during the study. Here, downward POC flux resulting from sedimentation of microphytoplankton was equivalent to $15-75 \%$ of the total. Increase in sedimentation of phytoplankton during the study can be related to an increase in the average size of phytoplankton cells. Transport of POC from surface waters to deeper depths resulting from sedimentation or grazing activity was equivalent to $<48 \%$ of total daily primary production, measured at $50 \mathrm{~m}$, while the same value for phytoplankton flux did not exceed $27 \%$ of the total. Zooplankton density was insufficient to exert either a positive (via faecal pellets) or negative (via reducing suspended phytoplankton concentration) effect on particulate carbon sedimentation. This resulted in algal sink being the most important mechanism in downward POC flux during the onset of the phytoplankton bloom period in the Marginal Ice Zone, even in the presence of pelagic tunicates.
\end{abstract}

KEY WORDS: Seasonal ice zone - Antarctica · Lazarev Sea $\cdot$ Vertical flux $\cdot$ POC $\cdot$ Phytoplankton · Zooplankton · Grazing

Resale or republication not permitted without written consent of the publisher

\section{INTRODUCTION}

Each year about $1 / 3$ of the Southern Ocean (the region south of the Subantarctic Front) experiences an advance and retreat of the sea-ice (Comiso \& Zwally

*Address for correspondence: University of Fort Hare.

E-mail: epakhomov@ufh.ac.za
1984). Dense phytoplankton blooms often accompany the receding ice and may persist in the Marginal Ice Zone (MIZ) for several weeks, extending for up to $200 \mathrm{n}$ miles in width (Smith \& Nelson 1985). It has been suggested that production associated with the MIZ may contribute between 40 and $60 \%$ to the annual primary production of the Southern Ocean (Smith \& Nelson 1986, Savidge et al. 1996). The fate of the photo- 
synthetically fixed carbon in this region is therefore of particular importance for the total carbon budget of the Southern Ocean (Smetacek et al. 1990). It was recently shown that in the continental seas the majority of primary production is partitioned through particulate rather than dissolved organic carbon, postulating the importance of zooplankton grazing in carbon transfer (Carlson et al. 1998).

Boyd \& Harrison (1999) suggested that the fate of phytoplankton in inshore regions of the ocean during the post-bloom periods is sedimentation and that pelagic recycling predominates outside bloom periods, while in offshore regions pelagic recycling predominates year-round. In the Southern Ocean, Smetacek et al. (1990) identified 2 basic loss type systems, e.g. 'loss' and 'retention' sensu Peinert et al. (1989), which eventually determined the magnitude and composition of vertical flux. The loss type system is characterized by the high downward carbon flux through either sedimentation of phytoplankton cells and phyto-detritus or feces of large metazoans, such as krill and salps. In the retention type system, high grazing pressure by copepods appears to induce high retention of carbon in the top layers of water and consequently low downward carbon flux (Smetacek et al. 1990).

Preliminary calculations conducted in the Lazarev Sea using the gut fluorescence technique suggested that prior and immediately after the 1994/95 drogue study, the sinking of phytoplankton cells may have represented the most important mechanism for the downward carbon transfer to depth (Froneman et al. 1997). However, results of other sediment trap studies indicate that within the MIZ, krill and copepods may contribute substantially to total downward particle flux (Schnack 1985, von Bodungen et al. 1986, Wefer 1989, Bathmann et al. 1991, Cadée et al. 1992).

From late December 1994 to early January 1995, a drogue with sediment traps was deployed for $12 \mathrm{~d}$ within the MIZ of the Lazarev Sea to investigate, in a 'lagrangian mode', the fate of biogenic material in the top $200 \mathrm{~m}$ layer of water during the onset of the phytoplankton bloom. This region is generally characterized by high krill biomass, and consequently the downward carbon flux was expected to be mainly grazer-mediated (Makarov \& Sysoeva 1983, Bathmann et al. 1991, Knox 1994). However, during the 1994/95 summer season, krill densities in the area of investigation were extremely low, never exceeding 0.7 ind. $\mathrm{m}^{-3}$ (Froneman et al. 1997). In contrast, concentrations of the salp Salpa thompsoni reached levels of ca. 4 ind. $\mathrm{m}^{-3}$, suggesting that regional carbon flux may have been altered as salps are considered to be more efficient repackagers of pelagic particles than krill (Perissinotto \& Pakhomov 1998a,b). The time series measurements in a lagrangian mode, e.g. following a drifting sediment trap to minimize the effects of horizontal advection, are scarce in the Southern Ocean (Karl et al. 1991) and elsewhere (Bender et al. 1992, Fasham et al. 1999). The main aims of this investigation are: (1) to study composition of sedimented material, and (2) to quantify the role played by biotic components of the ecosystem (algal sinking and grazing) in downward carbon flux during the onset of phytoplankton bloom in the iceedge zone of the Lazarev Sea.

\section{MATERIALS AND METHODS}

Phytoplankton, chlorophyll a (chl a), phaeopigments and particulate organic carbon (POC) dynamics and fluxes were investigated during the Southern Ocean Drogue and Ocean Flux Study (SODOFS) aboard the MV 'SA Agulhas' (Voyage 57), conducted between 28 December 1994 and 8 January 1995, in the seasonal ice zone of the Lazarev Sea (see Fig. 1). In order to track the same water body, a drogue (parachute type) was deployed at $300 \mathrm{~m}$ depth on 28 December 1997 and was followed for $12 \mathrm{~d}$. While tracking the drogue, continuous temperature and salinity measurements as well as phytoplankton, chl $a$ and POC samples were collected at fixed depths twice daily (around midday and midnight) using a Neil Brown MK III CTD-profiler with 81 Niskin bottles mounted on a 12 bottle rosette system (General Oceanics, Miami Florida). In order to avoid diel variability, results of the day and night sampling were averaged (except for POC) to represent daily observations. At each station, water samples were collected at 6 standard depths: $0,10,20,50,100$, 125 and $200 \mathrm{~m}$.

Water column phytoplankton, pigments, primary production and POC. Fifty millilitre aliquots of seawater from each standard depth were fixed with a glutaraldehyde-Lugol solution for taxonomic analysis of phytoplankton (Rousseau et al. 1990). In the laboratory, phytoplankton cells were counted with a noninverted light microscope furnished with a counting grid (Semina 1978). The whole sample was gently mixed and pico- $(<2 \mu \mathrm{m})$ and the most abundant nanoplankton (2 to $20 \mu \mathrm{m}$ ) algae were counted in a Fuchs-Rosental counting chamber at $400 \times$ magnification. The samples were then left to settle for a week and slowly decanted through a glass tube covered with 2 layers of fine mesh nylon gauze. After gentle mixing, part of the remaining sample was removed with a glass tube and placed into a $0.05 \mathrm{ml}$ chamber. Microplankton cells $(>20 \mu \mathrm{m})$ were counted at $200 \times$ magnification. In order to count rare phytoplankton forms, a special $1.0 \mathrm{ml}$ chamber was used. Many algae could, however, only be identified to genus level. Flagellates and coccolithiphorides were encountered in the size groups 
$2-4,4-6,6-10,10-15$ and $15-30 \mu \mathrm{m}$ only. The biovolume of algae cells was calculated from the volumes of appropriate stereometrical bodies (Smayda 1978). The average cell volume of each group was used to calculate the carbon content of the cells according to Strathmann (1967). No attempt was made to distinguish between heterotrophic and autotrophic cells. Thus, estimates of dinoflagellate and flagellate abundance and carbon content, and thereby the total phytoplankton carbon (PPC), may include mixotrophic and heterotrophic cells.

Water column (0 to $200 \mathrm{~m}$ ) chl a and phaeopigments were extracted from $250 \mathrm{ml}$ aliquots in $90 \%$ acetone for $12 \mathrm{~h}$ in the dark at $-18^{\circ} \mathrm{C}$. Concentrations were calculated from fluorescence readings on a Turner Designs 111 fluorometer before and after acidification with $\mathrm{HCl}$ (Parsons et al. 1984). Pigment fractionation into pico- $(<2 \mu \mathrm{m})$, nano- $(2$ to $20 \mu \mathrm{m})$ and micro$(>20 \mu \mathrm{m})$ size classes was carried out by serial filtration (vacuum $<5 \mathrm{~cm} \mathrm{Hg}$ ) at all stations. For this purpose, Whatman GF/C, $2.0 \mu \mathrm{m}$ Nucleopore and $20 \mu \mathrm{m}$ Nitex filters were used in a multiple serial filtration manifold.

Estimates of primary production rates were carried out daily following the Joint Global Ocean Flux Study protocol (JGOFS 1990). A detailed description of the procedure can be found in Froneman et al. (1997).

For analysis of total POC, $200 \mathrm{ml}$ aliquots from each standard depth were filtered on pre-combusted Whatman $\mathrm{GF} / \mathrm{F}$ filters, stored in a freezer $\left(-20^{\circ} \mathrm{C}\right)$ and later analysed on a Leeman Laboratory CEC 440 CHN analyser after removal of carbonate with fumes of concentrated $\mathrm{HCl}$.

Sediment trap phytoplankton, pigments and POC. Nine sets of sediment traps were deployed during the drogue study (see Fig. 1). Vertical flux of particulate organic material and pigments were collected at 6 depths between 20 and $80 \mathrm{~m}$ (at $10 \mathrm{~m}$ intervals) and at 3 depths between 80 and $200 \mathrm{~m}$ (at $40 \mathrm{~m}$ intervals) using sediment traps. The sediment traps (KC maskiner og laboratorieudstyr, Copenhagen, Denmark) comprised of parallel cylinders mounted in a gimballed frame, equipped with a vane to ensure that the cylinders were always positioned vertically and never shaded each other. The traps measured $0.072 \mathrm{~m}$ in diameter and $0.45 \mathrm{~m}$ in height $(\mathrm{H} / \mathrm{D}$ ratio $=6.25)$. The traps were deployed for 47 to $48 \mathrm{~h}$. Poison was not applied and therefore grazing and bacterial decomposition may have occurred in the sediment traps during the deployment.

After recovery, contents of the sediment traps were transferred to bottles and kept cold and dark. Samples were never kept more than $4 \mathrm{~h}$ before subsampling. Each sample was thoroughly mixed and a bird pipette was used for subsampling. Fifty $\mathrm{ml}$ aliquots of the sample from each depth were fixed with a glutaraldehyde-Lugol solution for taxonomic analysis of phyto- plankton as described above. Total PPC was calculated using the average cell volume:carbon content ratio of each group according to Strathmann (1967). Quadruplicate samples $(\sim 200 \mathrm{ml})$ from each cylinder were taken and filtered for analysis of POC, chl $a$ and phaeopigments on pre-combusted Whatman GF/F filters followed by manual removal of all visible metazoans. Samples for chl a and phaeopigments were analysed immediately after subsampling using a Turner Designs AU-10 fluorometer as described above. POC samples were stored in a freezer $\left(-20^{\circ} \mathrm{C}\right)$ and were later analysed on a Leenam Laboratory CEC 440 $\mathrm{CHN}$ analyser after removal of carbonate with fumes of concentrated $\mathrm{HCl}$.

Fifty $\mathrm{ml}$ aliquots of the trap sample from 50, 70, 120, 160 and $200 \mathrm{~m}$ depths (e.g. below the euphotic zone) were used to enumerate faecal pellets, metazoan (mainly Copepoda) eggs and foraminiferans. These were counted and measured using a dissecting microscope. The length and width of pellets were measured to calculate faecal pellet volume (FPV) according to Edler (1979). To calculate faecal pellet carbon (FPC), the total FPV and an average POC:FPV ratio of $0.069 \mathrm{mg} \mathrm{C} \mathrm{mm}^{-3}$ was applied (E. Arashkevich unpubl. results). An average value of $0.32 \mu \mathrm{gC} \mathrm{egg}^{-1}$ and $0.08 \mu \mathrm{g} C$ foraminifera ${ }^{-1}$ were applied to calculate metazoan egg and foraminiferan carbon (EFC) (E. Arashkevich unpubl. results).

Daily loss rates (\%) were calculated using integrated concentrations of chl a from the depth above the sediment trap or using depth integrated primary production. Potential faecal pellet production was estimated from herbivorous zooplankton grazing rates assuming an average assimilation efficiency of $70 \%$ (Downs \& Lorenzen 1985).

Zooplankton grazing. Meso- (0.5 to $20 \mathrm{~mm})$ and macrozooplankton (>20 mm) were collected and grazing rates of the most abundant herbivorous species were measured at the three $24 \mathrm{~h}$ stations. Samples were collected every $4 \mathrm{~h}$ with oblique Bongo net (300 and $500 \mu \mathrm{m}$ mesh) tows between 300 and $0 \mathrm{~m}$. The $24 \mathrm{~h}$ stations coincided with Drogues 2, 4 and 6. The $300 \mu \mathrm{m}$ mesh sample was immediately fixed in $4 \%$ hexamine buffered formalin for taxonomic identification and enumeration of zooplankton in the laboratory. The $500 \mu \mathrm{m}$ mesh sample was used to estimate zooplankton grazing impact on phytoplankton using the in situ gut fluorescence technique (Perissinotto 1992, Perissinotto \& Pakhomov 1996).

At each 24 h station, 3 to 10 specimens of each species were processed within 5 min of collection to monitor initial gut pigment concentrations. The gut evacuation rate experiments consisted of in vitro incubations of freshly caught specimens of the 10 most abundant herbivorous species in 201 polyethylene containers, 


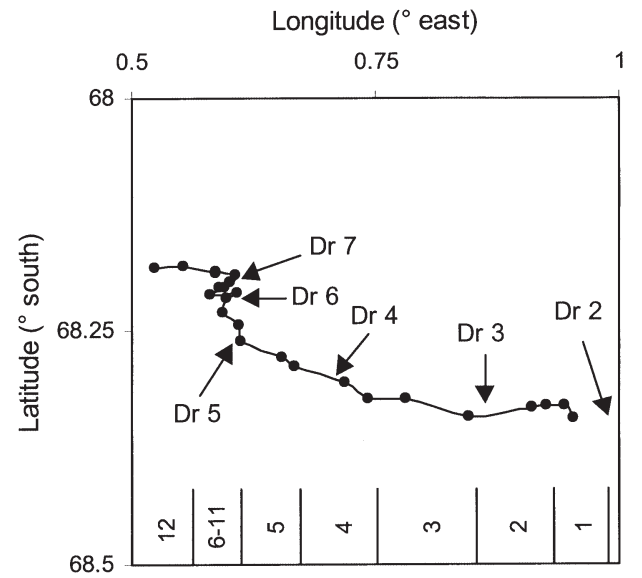

Fig. 1. Drogue track in the Lazarev Sea between 28 December 1994 and 12 January 1995. Points and arrows show the CTD stations and drogue deployment locations respectively

filled with surface water and filtered through a $0.2 \mu \mathrm{m}$ Milli-Q filtration system to which charcoal particles $(<100 \mu \mathrm{m})$ were added to keep zooplankton under continuous feeding conditions (Perissinotto \& Pakhomov 1996). The incubations ranged from 1 to $5 \mathrm{~h}$, with gut fluorescence measured at 5 to 20 min intervals for the first 1 to $2 \mathrm{~h}$ and at 0.5 to $1 \mathrm{~h}$ intervals thereafter until the end of the experiment. Three to 5 specimens were collected at each time interval. Gut evacuation rate constants $\left(k, h^{-1}\right)$ were then derived from the slope of the regression versus time (Perissinotto \& Pakhomov 1996).

To estimate gut pigment destruction efficiency $\left(b^{\prime}\right)$, freshly caught animals were incubated in particle-free seawater for 4 to $24 \mathrm{~h}$ to allow the animals to empty their guts. Specimens (5 to 10 copepods and 1 to 2 euphausiids or salps per jar) were then incubated for 1 to $2 \mathrm{~h}$ in $1 \mathrm{l}$ polyethylene containers containing natural seawater. The gut pigment destruction efficiency was estimated using the 2 compartment (phytoplankton and grazer) pigment budget approach. A comparison of the pigment budgets in the control (without grazers) and experimental treatment was then carried out. Any significant loss in the pigment budget from the experimental treatment (with grazers) was then attributed to gut destruction of phytoplankton pigments (Perissinotto \& Pakhomov 1996). Previous studies conducted in the Antarctic have demonstrated that the gut passage time of copepods may be $<1 \mathrm{~h}$, suggesting that the gut destruction efficiency of the copepods may have been overestimated during this study. However, since no faecal pellets were observed at the end of the incubations, the overestimation appears to have been negligible.

In all the experiments, gut pigments were extracted in $10 \mathrm{ml}$ polyethylene tubes $\left(1 \mathrm{ind}\right.$. tube ${ }^{-1}$ for macro- plankton; 3 to 10 ind. tube ${ }^{-1}$ for mesozooplankton) with 8 to $10 \mathrm{ml}$ of $100 \%$ methanol and stored at $-20^{\circ} \mathrm{C}$ for $12 \mathrm{~h}$. After centrifugation at $5000 \mathrm{rpm}(1745 \times g)$, the pigment content of the methanol was measured before and after acidification using a Turner Designs 111 fluorometer (Mackas \& Bohrer 1976). Pigment contents were then expressed in terms of total pigments per individual and calculated according to Strickland \& Parsons (1968) as modified by Conover et al. (1986). Where the chlorophyll:phaeopigment ratio in the gut content was higher than 0.25 , total pigment levels were corrected according to Baars \& Helling (1985).

Daily ingestion rates $\left(I\right.$, ng pig. ind. $\left.{ }^{-1} \mathrm{~d}^{-1}\right)$ were estimated from the relation of Perissinotto (1992): $I=$ $\mathrm{k} G /\left(1-b^{\prime}\right)$, where $G$ is an integrated value (over $24 \mathrm{~h}$ period assuming a linear decay in gut pigment) of gut pigments (ng pig ind. ${ }^{-1} \mathrm{~d}^{-1}$ ), $\mathrm{k}$ is the gut evacuation rate

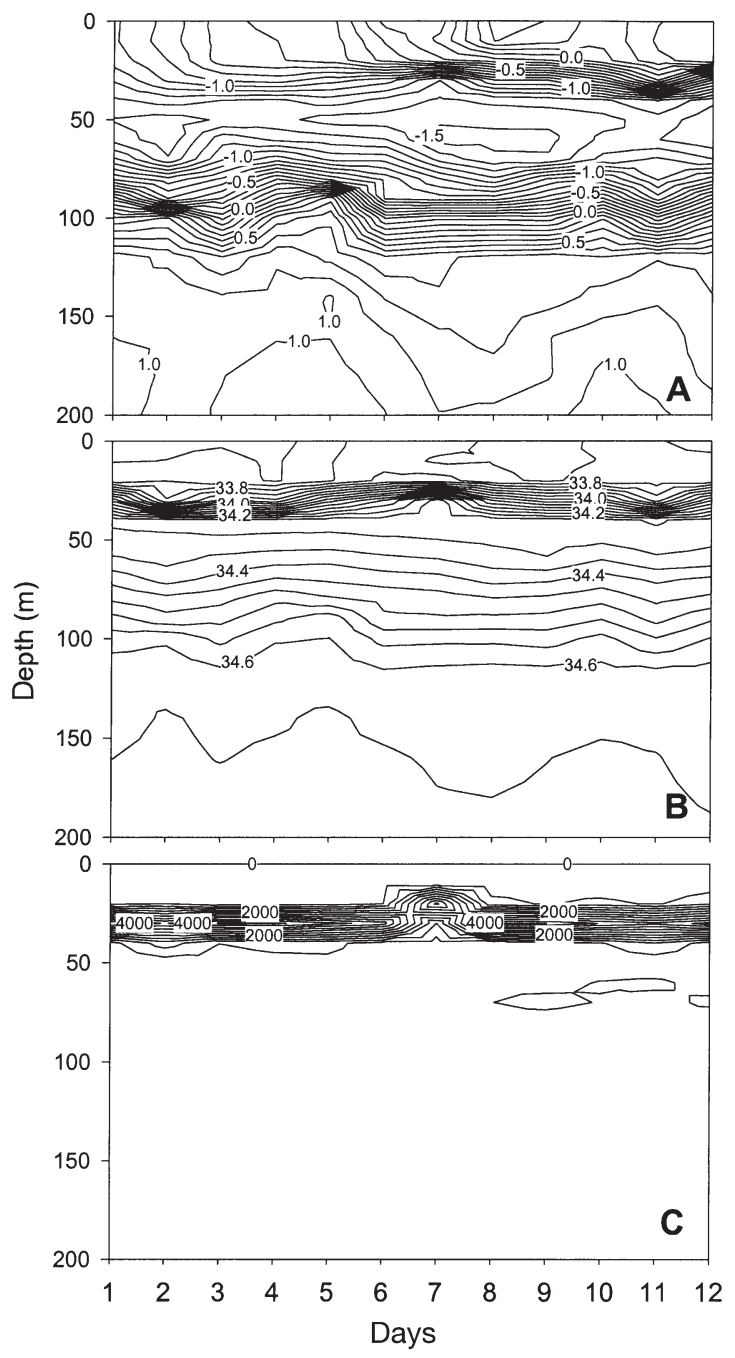

Fig. 2. Vertical distribution $(\mathrm{m})$ of $(\mathrm{A})$ temperature $\left({ }^{\circ} \mathrm{C}\right)$, (B) salinity (psu) and (C) stability $\left(\times 10^{-8} \mathrm{~m}^{-1}\right)$ during the 1994/95 drogue study in the Lazarev Sea 


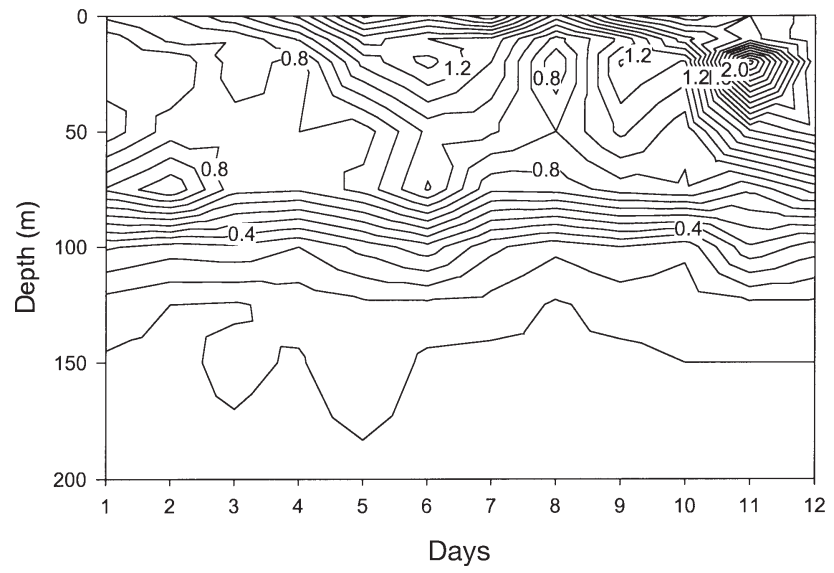

Fig. 3. Vertical distribution (m) of total chl a during the 1994/95 drogue study in the Lazarev Sea

constant $\left(\mathrm{h}^{-1}\right)$, and $b^{\prime}$ is efficiency of gut pigment destruction. In order to estimate the community grazing impact, species abundance data were combined with the individual ingestion rates. To convert pigment concentrations into autotrophic carbon (C), the POC:pigment (chl $a+$ phaeopigments) ratio, obtained during Drogues 2, 4 and 6 in the top $200 \mathrm{~m}$ water column (137, 118 and 112 respectively), was employed. The grazing impact was then expressed as \% integrated chl a stock and \% daily primary production consumed per day.

\section{RESULTS}

\section{Physical environment}

During the course of the study, the drogue drifted $\sim 25 \mathrm{n}$ miles in a westerly direction for $12 \mathrm{~d}$ (Fig. 1). Conditions during the entire experiment were characterised by low wind speeds, ranging from 1.4 to 19.8 knots, and high surface light intensities, varying between 564 and $2797 \mu \mathrm{E} \mathrm{m}^{-2} \mathrm{~d}^{-1}$ (Froneman et al. 1996). At the time of the drogue deployment, the sea surface was free of pack ice. The pack ice edge was found approximately $20 \mathrm{n}$ miles to the south from the point of the drogue deployment (G. Rigg pers. comm.).

At the beginning of the drogue study, seawater temperatures ranged from below zero down to $100 \mathrm{~m}$ and were only half a degree colder between 40 and $70 \mathrm{~m}$ depths than in the upper layer (Fig. 2A). No strong thermocline was evident at the beginning of the study, while a well-developed halocline was already established (Fig. 2B). The distinct trend was an increase in the surface seawater temperature, clearly indicating that the summer capping of colder winter waters had occurred during the study (Fig. 2A,B). From Day 5 onwards, the upper water column appeared to be strongly stratified with a sharp pycnocline evident in the upper 20 to $30 \mathrm{~m}$ layer (Fig. 2). A subsurface (40 to $60 \mathrm{~m}$ ) colder and more saline water intrusion occurred between Days 5 and 10, being most extensive during Days 7 to 9 (Fig. 2A). This intrusion did not dramatically affect the physico-chemical structure of the upper water column. However, coupled with the summer capping the intrusion resulted in the shallowing of pycnocline after Day 7 (Fig. 2C).

\section{Chl $a$ and primary production dynamics}

With the exception of the first $3 \mathrm{~d}$ of the experiment, $>50 \%$ of total chl a biomass was concentrated within the top $50 \mathrm{~m}$ (Fig. 3). A subsurface (at $\sim 75 \mathrm{~m}$ ) enhancement of chl a was also observed at the beginning of the drogue study. However, after the development of a strong pycnocline on Day 5, chl a concentrations exceeding $1 \mathrm{mg} \mathrm{m}^{-3}$ were found almost exclusively in the upper mixed layer (Fig. 3). After Day 10, however, maximum chl a biomass was recorded at depths corresponding to approximately $50 \mathrm{~m}$ (Fig. 3). Surface total chl a biomass doubled between Day 1 and 5 (from 0.8 to $1.6 \mathrm{mg} \mathrm{m}^{-3}$ ) and then showed a tendency to stabilise (Fig. 4A). However, the depth-integrated chl a biomass displayed an increasing trend throughout the experiment (Fig. 4B). Size-fractionated surface chl a data indicate that all the changes in biomass were
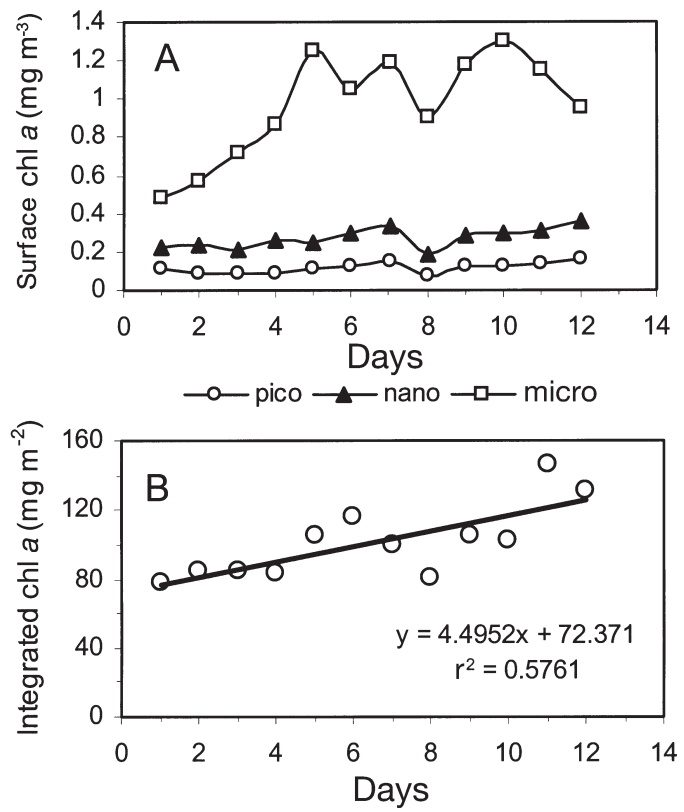

Fig. 4. (A) Surface size-fractionated and (B) total depth-integrated chl a temporal distribution during the 1994/95 drogue study in the Lazarev Sea 


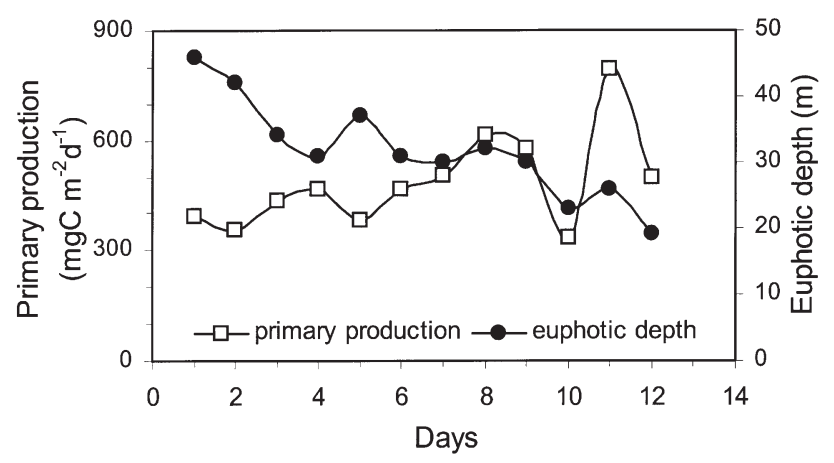

Fig. 5. Daily primary production and euphotic depth temporal variability during the 1994/95 drogue study in the Lazarev Sea

associated with the microphytoplankton size fraction (Fig. 4A). Surface- and depth-integrated chl a densities showed significant positive correlation $(p<0.05)$ with temperature (surface and depth averaged) and surface salinity, which accounted for $\geq 58 \%$ of $\mathrm{chl}$ a variability. During the course of the drogue study the euphotic depth decreased from 46 to $20 \mathrm{~m}$ (Fig. 5). Total primary production raged from 355 to $796 \mathrm{mg} \mathrm{C} \mathrm{m}^{-2} \mathrm{~d}^{-1}$ with the highest values recorded towards the completion of the study (Fig. 5).

\section{Suspended and sedimented phytoplankton}

Flagellates of nano- and pico-size classes dominated the phytoplankton community, accounting for $>90 \%$ of total cells counted during the drogue study. Their abundance decreased by $\sim 3.5$-fold throughout the experiment. This explained $97 \%$ of total phytoplankton abundance variability $\left(\mathrm{r}^{2}=0.97, \mathrm{p}<0.005\right)$ during the drogue study.

Total PPC flux at $200 \mathrm{~m}$ depth ranged from 24 to $48 \mathrm{mg} \mathrm{C} \mathrm{m}^{-2} \mathrm{~d}^{-1}$ and was the lowest during Drogue 5. Phytoplankton composition recovered in the sediment trap at $200 \mathrm{~m}$ was similar to that found in the top $200 \mathrm{~m}$ layer of water with flagellates and diatoms accounting for 49 to 85 and 8 to $48 \%$ of total PPC, respectively (Fig. 6).

\section{Vertical flux of particulate biogenic matter}

During the entire drogue study, the vertical flux of POC and chl a was the highest in the upper water column $(<80 \mathrm{~m})$ and decreased with depth (Figs. $7 \& 8)$. The vertical flux of phaeopigments was generally highest between 50 and $80 \mathrm{~m}$ depths and only on 2 occasions (Drogues 3 and 7 ) at $20 \mathrm{~m}$ (Fig. 8). The chlorophyll:phaeopigment ratio was highest $(>1.5)$ in the 20 and $30 \mathrm{~m}$ depth strata. The ratio decreased with increasing depth, with values $<1$ below $80 \mathrm{~m}$ depth with only 2 exceptions observed during Drogues 2 and 7 (Fig. 9). POC flux ranged from 155 to $295 \mathrm{mg} \mathrm{C} \mathrm{m}^{-2}$ $\mathrm{d}^{-1}$ and from 60 to $110 \mathrm{mg} \mathrm{C} \mathrm{m}^{-2} \mathrm{~d}^{-1}$ at 20 and $200 \mathrm{~m}$ depths, respectively (Fig. 7). During the course of the drogue study POC flux almost doubled, while chl $a$ and phaeopigment fluxes nearly tripled. Chl $a$ and phaeopigment fluxes ranged from 0.55 to $1.59 \mathrm{mg} \mathrm{m}^{-2} \mathrm{~d}^{-1}$ and from 0.26 to $0.76 \mathrm{mg} \mathrm{m}^{-2} \mathrm{~d}^{-1}$ at $20 \mathrm{~m}$ depth respectively (Fig. 8).

Contribution of PPC flux to the total POC flux was generally highest either in the upper $70 \mathrm{~m}$ of the water column (range 11 to $70 \%$ of the total) or between 160 and $200 \mathrm{~m}$ (15 to $86 \%$ ) (Fig. 10, Table 1). With the exception of Drogue 7, contribution of FPC flux to total POC flux was always $<1 \%$ within the top $160 \mathrm{~m}$. The highest contribution of faecal pellets (up to $9 \%$, Drogue 2) was generally observed at $200 \mathrm{~m}$ depth (Fig. 10, Table 1). During Drogue 7, FPC contribution was consistently higher throughout the water column, accounting for 6 to $16 \%$ of the total POC flux (Fig. 10, Table 1). Throughout the drogue study, oval faecal pellets (mainly copepod pellets, $100 \times 50 \mu \mathrm{m}$ in size) accounted for $>70 \%$ of all pellets found in the sediment traps at all depths. Metazoan EFC generally contributed $\leq 7 \%$ to the total POC flux, with the highest contribution $(<13 \%)$ recorded during Drogues 5 and 7 (Fig. 10, Table 1).
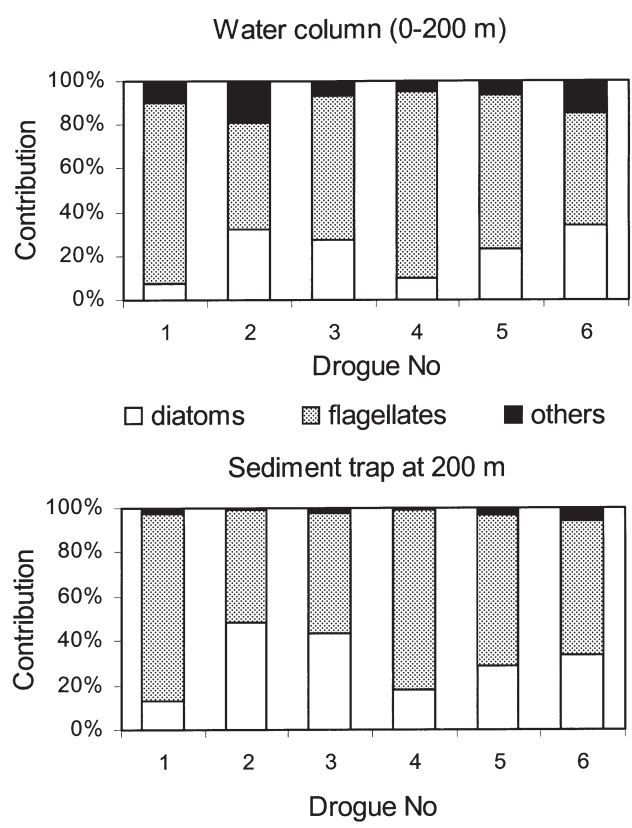

Fig. 6. Phytoplankton group composition (by phytoplankton carbon [PPC]) in the 0 to $200 \mathrm{~m}$ water column and in the $200 \mathrm{~m}$ sediment trap during the 1994/95 drogue study in the Lazarev Sea 


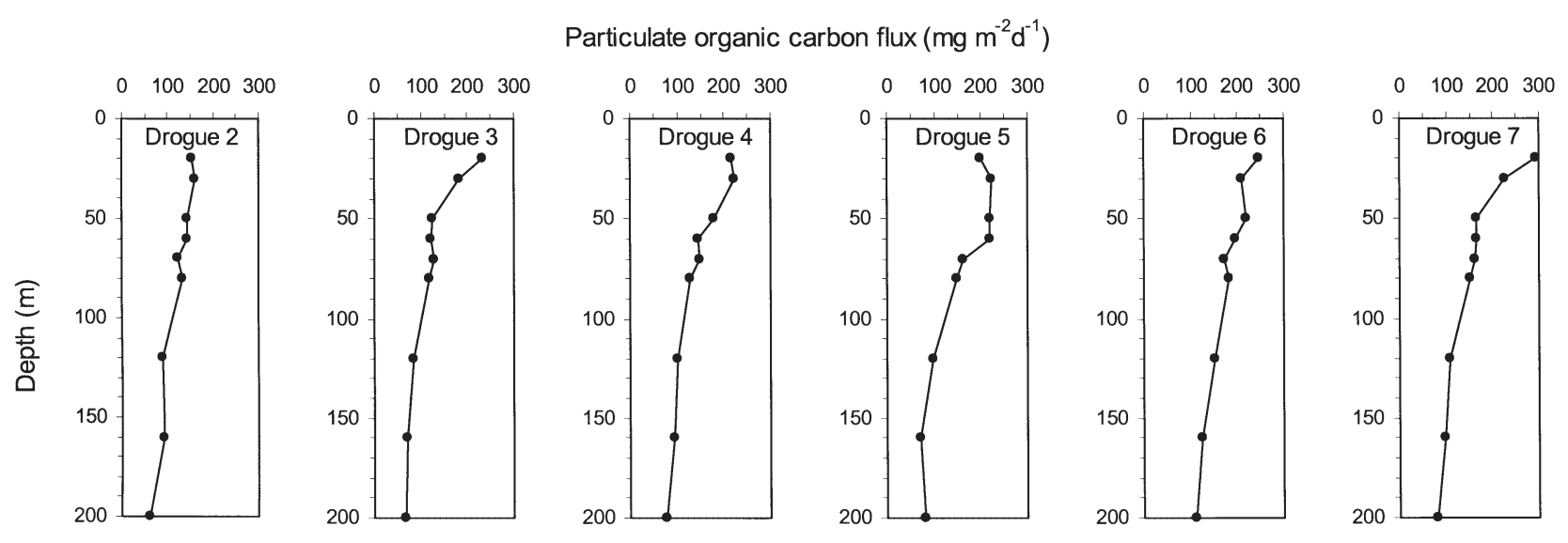

Fig. 7. Downward flux of particulate organic carbon measured in sediment traps in Drogues 2 to 7 during the $1994 / 95$ drogue study in the Lazarev Sea

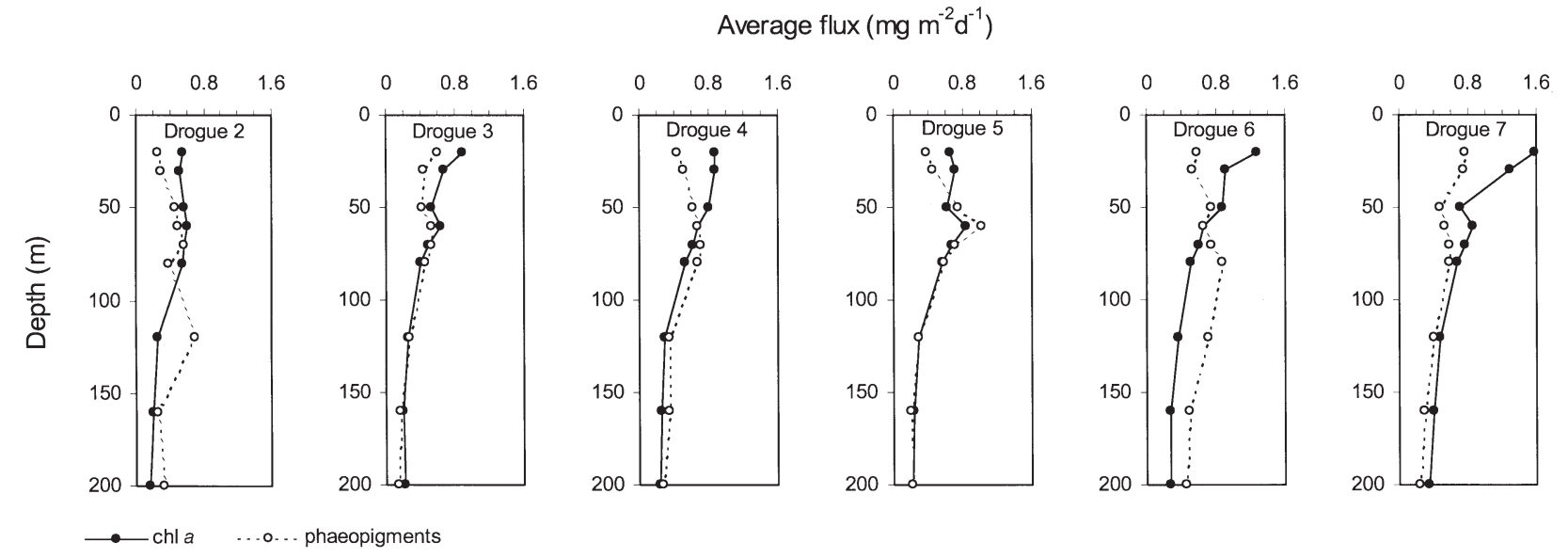

Fig. 8. Downward flux of chl $a$ and phaeopigments measured in sediment traps in Drogues 2 to 7 during the 1994/95 drogue study in the Lazarev Sea

\section{Chlorophyll: phaeopigment ratio}
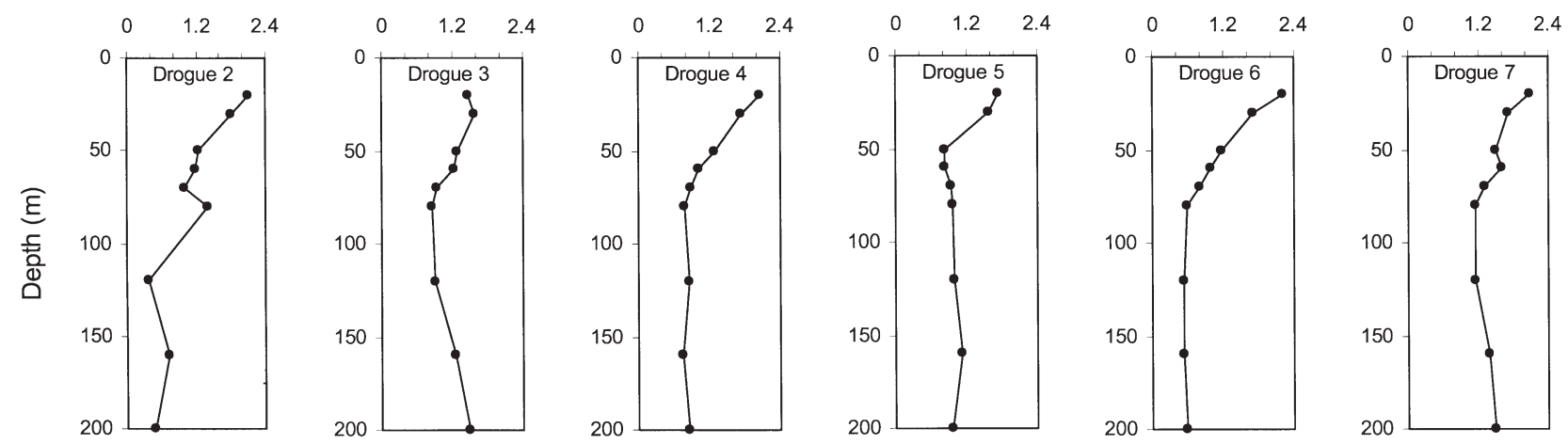

Fig. 9. Chlorophyll:phaeopigment ratio measured in sediment traps in Drogues 2 to 7 during the 1994/95 drogue study in the Lazarev Sea 


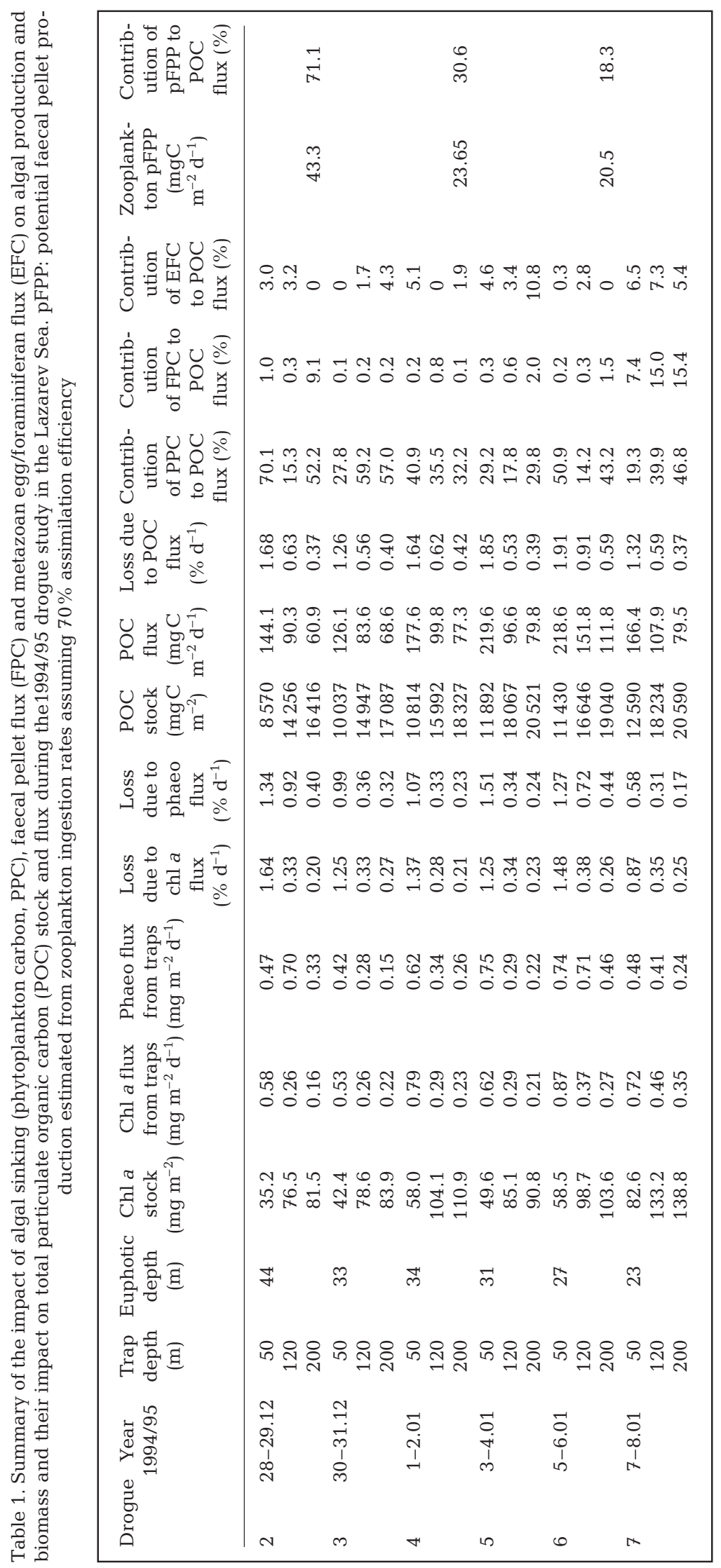

\section{Daily loss rates of biogenic material and microplankton}

Daily loss of POC expressed as \% of total POC standing stock was highest at $50 \mathrm{~m}$ depth and relatively constant (1.3 to $1.9 \%$ ) throughout the entire drogue study. It decreased with increasing depth and was lowest, range 0.4 to $0.6 \%$, at $200 \mathrm{~m}$ depth (Table 1). Similarly to POC, daily loss of chl a expressed as \% of total chl a stock was the highest immediately below the euphotic zone (at $50 \mathrm{~m}$ ) ranging from 0.9 to $1.6 \%$ of total. The lowest values at $50 \mathrm{~m}$ were observed during Drogue 7 (Table 1). POC decreased with the increasing depth, accounting for only 0.2 to $0.3 \%$ of total chl a stock at $200 \mathrm{~m}$ depth (Table 1). Daily loss of phaeopigments expressed as \% of total chl a stock was almost identical to chl a loss, ranging from 0.6 to 1.3 and 0.2 to $0.4 \%$ at 50 and $200 \mathrm{~m}$ depths respectively (Table 1).

During the drogue study, daily loss of CPP estimated via chl a flux ranged from 5.5 to 9.5 and 1.9 to $3 \%$ at 50 and $200 \mathrm{~m}$ depths respectively (Table 2). Daily loss of CPP via POC flux was substantially higher, ranging from 26 and 48 and 12 to $25 \%$ at 50 and $200 \mathrm{~m}$ depths, respectively (Table 2). Daily loss of CPP via PPC flux generally decreased during the drogue study and was equivalent to $5-27$ and $4-11 \%$ at 50 and $200 \mathrm{~m}$ depths respectively (Table 2). In contrast, daily loss of CPP via FPC flux increased towards the end of the study, ranging from $<0.1$ to $\sim 2 \%$ of the total (Table 2).

During the experiment, daily loss rates of microplankton at $200 \mathrm{~m}$ depth ranged from 0.1 to $2.3 \%$, showing a clear increasing trend towards the end of the investigation (Table 3). Group-specific daily loss rates were the highest (range 0.1 to $2.5 \%$ ) for diatoms, which displayed an identical trend with loss rates of total microplankton. Phaeocystis sp. cells showed the highest loss rates $(0.7$ to $1.2 \%$ ) during Drogues 2 and 7 (Table 3). Daily loss rates for the remaining microplankton groups ranged from $<0.1$ to $0.2 \%$ (Table 3 ).

\section{Zooplankton composition and grazing}

Total abundance of zooplankton in the top 200 or $300 \mathrm{~m}$ water layer varied between 


\section{Contribution to POC flux (\%)}
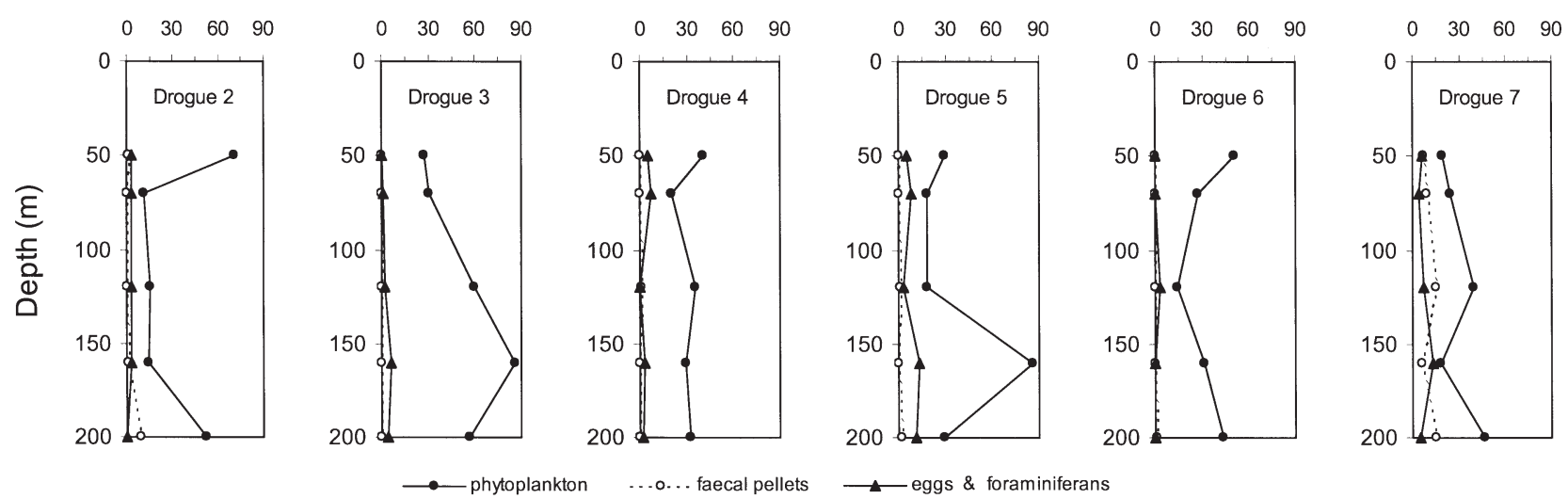

Fig. 10. Phytoplankton (PPC), faecal pellet (FPC) and metazoan eggs/foraminiferans (EFC) contribution to total downward particulate organic carbon (POC) flux measured in sediment traps in Drogues 2 to 7 during the 1994/95 drogue study in the Lazarev Sea

Table 2. Loss rates of $\mathrm{chl} a$, POC, phytoplankton (PPC), FPC and zooplankton grazing expressed as \% of primary production during the 1994/95 drogue study in the Lazarev Sea

\begin{tabular}{|c|c|c|c|c|c|c|c|}
\hline Drogue & $\begin{array}{l}\text { Depth } \\
\text { (m) }\end{array}$ & $\begin{array}{l}\text { Primary production } \\
\qquad\left(\mathrm{mg} \mathrm{C} \mathrm{m}^{-2} \mathrm{~d}^{-1}\right)\end{array}$ & $\begin{array}{l}\text { Loss due to } \\
\text { chl a flux } \\
\left(\% \mathrm{~d}^{-1}\right)\end{array}$ & $\begin{array}{l}\text { Loss due to } \\
\text { POC flux } \\
\left(\% d^{-1}\right)\end{array}$ & $\begin{array}{l}\text { Loss due to } \\
\text { PPC flux } \\
\left(\% d^{-1}\right)\end{array}$ & $\begin{array}{l}\text { Loss due to } \\
\text { FPC flux } \\
\left(\% \mathrm{~d}^{-1}\right)\end{array}$ & $\begin{array}{l}\text { Loss due to } \\
\text { zooplankton grazing } \\
\left(\% \mathrm{~d}^{-1}\right)\end{array}$ \\
\hline \multirow[t]{3}{*}{2} & 50 & 375 & 7.7 & 38.4 & 26.9 & 0.4 & \\
\hline & 120 & & 3.4 & 24.1 & 3.7 & 0.1 & \\
\hline & 200 & & 2.1 & 16.3 & 8.5 & 1.5 & 36.6 \\
\hline \multirow[t]{3}{*}{3} & 50 & 451 & 5.9 & 27.9 & 7.8 & 0.03 & \\
\hline & 120 & & 2.9 & 18.5 & 11.0 & 0.03 & \\
\hline & 200 & & 2.5 & 15.2 & 8.7 & 0.03 & \\
\hline \multirow[t]{3}{*}{4} & 50 & 422 & 8.7 & 42.1 & 17.2 & 0.1 & \\
\hline & 120 & & 3.4 & 23.6 & 8.4 & 0.2 & \\
\hline & 200 & & 2.7 & 18.3 & 5.9 & 0.02 & 17.0 \\
\hline \multirow[t]{3}{*}{5} & 50 & 559 & 5.5 & 39.3 & 11.5 & 0.1 & \\
\hline & 120 & & 2.6 & 17.3 & 3.1 & 0.1 & \\
\hline & 200 & & 1.9 & 14.3 & 4.3 & 0.3 & \\
\hline \multirow[t]{3}{*}{6} & 50 & 455 & 9.5 & 48.1 & 24.5 & 0.1 & \\
\hline & 120 & & 4.1 & 33.4 & 4.8 & 0.1 & \\
\hline & 200 & & 3.0 & 24.6 & 10.6 & 0.4 & 15.0 \\
\hline \multirow[t]{3}{*}{7} & 50 & 647 & 5.5 & 25.7 & 5.0 & 1.9 & \\
\hline & 120 & & 3.6 & 16.7 & 6.7 & 2.5 & \\
\hline & 200 & & 2.7 & 12.3 & 5.8 & 1.9 & \\
\hline
\end{tabular}

Table 3. Loss rates of different groups of phytoplankton at $200 \mathrm{~m}$ depth expressed as \% of total phytoplankton stock in the 0 to $200 \mathrm{~m}$ water layer during 1994/95 drogue study in the Lazarev Sea

\begin{tabular}{|c|c|c|c|c|c|c|}
\hline Drogue & Diatoms & Flagellates & Dinoflagellates & Phaeocystis sp. & Silicoflagellates & Total \\
\hline 2 & 0.1 & 0.1 & $<0.1$ & 1.2 & $<0.1$ & 0.1 \\
\hline 3 & 0.2 & $<0.1$ & $<0.1$ & $<0.1$ & 0.1 & 0.2 \\
\hline 4 & 0.1 & 0.1 & 0.1 & 0.1 & $<0.1$ & 0.1 \\
\hline 5 & 0.7 & 0.1 & $<0.1$ & $<0.1$ & $<0.1$ & 0.6 \\
\hline 6 & 2.5 & 0.2 & 0.2 & $<0.1$ & 0.1 & 2.3 \\
\hline 7 & 2.2 & 0.1 & 0.2 & 0.6 & $<0.1$ & 2.0 \\
\hline
\end{tabular}


Table 4. Mean abundance (ind. $\mathrm{m}^{-3} \pm \mathrm{SD}$ ) of the 11 most important zooplankton species during the 1994/95 drogue study in the Lazarev Sea. -: not recorded

\begin{tabular}{|lccr|}
\hline Taxon & Drogue 2 & Drogue 4 & Drogue 6 \\
\hline Rhincalanus gigas & $0.711 \pm 0.294$ & $2.167 \pm 0.080$ & $0.676 \pm 0.278$ \\
Calanus propinquus & $0.681 \pm 0.553$ & $1.252 \pm 0.210$ & $0.601 \pm 0.913$ \\
Calanoides acutus & $4.266 \pm 2.121$ & $3.169 \pm 0.255$ & $1.706 \pm 0.727$ \\
Metridia gerlachei & $3.370 \pm 1.228$ & $3.833 \pm 2.477$ \\
Clausocalanus and Ctenocalanus & $0.927 \pm 0.625$ & $4.835 \pm 0.091$ & $0.923 \pm 0.529$ \\
Oithona spp. & $1.556 \pm 1.295$ & $0.500 \pm 0.084$ & $3.594 \pm 3.793$ \\
Euphausia superba, juveniles & $0.002 \pm 0.004$ & $6.589 \pm 0.719$ & $0.001 \pm 0.001$ \\
E. superba, subadults/adults & $0.002 \pm 0.004$ & - & - \\
Thysanoessa macrura, juveniles & $0.100 \pm 0.065$ & - & $0.624 \pm 0.434$ \\
T. macrura, subadults & $0.024 \pm 0.025$ & $0.467 \pm 0.101$ & $0.060 \pm 0.124$ \\
T. macrura, adults & $0.003 \pm 0.009$ & $0.008 \pm 0.004$ & $0.001 \pm 0.005$ \\
Limacina spp. & $0.006 \pm 0.010$ & - & $0.009 \pm 0.014$ \\
Salpa thompsoni & $0.618 \pm 0.274$ & $0.008 \pm 0.004$ & $0.049 \pm 0.023$ \\
Total herbivores & $12.265 \pm 4.381$ & $0.836 \pm 0.086$ & $12.077 \pm 5.763$ \\
Total zooplankton & $15.646 \pm 5.495$ & $19.831 \pm 1.435$ & $16.833 \pm 7.055$ \\
Depth sampled (m) & $0-300$ & $26.478 \pm 1.802$ & $0-300$ \\
& & $0-200$ & \\
\hline
\end{tabular}

15.6 and 26.5 ind. $\mathrm{m}^{-3}$. The lowest and highest zooplankton abundances were recorded during Drogues 2 and 4 respectively (Table 4). Copepods, represented mainly by Rhincalanus gigas (copepodites IV-VI), Calanus propinquus (mainly adults), Calanoides acutus (mostly copepodites III-IV), Metridia gerlachei (copepodites IV-V), Oithona spp., Clausocalanus spp. and Ctenocalanus spp. were the most numerous, contributing between 67 and $73 \%$ to the total abundance (Table 4). Contribution of other groups, particularly euphausiids, pteropods and salps, never exceeded $5 \%$ of the total. During the drogue study, the 11 most abundant taxa which were used in grazing studies comprised 72 to $78 \%$ of total zooplankton abundance (Table 4).

Individual ingestion rates of herbivorous zooplankters are presented in Table 5. In general, ingestion rates of Rhincalanus gigas, Calanus propinquus and Metridia gerlachei decreased, while ingestion rates of Calanoides acutus and Limacina spp. increased during the course of the drogue study (Table 5).

The potential community grazing impact of the 4 most abundant zooplankton groups during the drogue study are presented in Table 6. Total ingestion rate ranged from 0.6 to $1.1 \mathrm{mg}$ pig. $\mathrm{m}^{-2} \mathrm{~d}^{-1}$ and 68.4 to $144.2 \mathrm{mg} \mathrm{C} \mathrm{m}^{-2} \mathrm{~d}^{-1}$ (Table 6). These ingestion rates cor-

Table 5. Ingestion rates of 11 most abundant herbivorous zooplankton species during the 1994/95 drogue study in the Lazarev Sea. Roman numerals show different zooplankton stages

\begin{tabular}{|c|c|c|c|c|}
\hline \multirow[t]{2}{*}{ Taxon } & \multicolumn{4}{|c|}{ Ingestion rates (ng pig. ind. ${ }^{-1} \mathrm{~d}^{-1}$ ) } \\
\hline & Drogue 2 & Drogue 4 & Drogue 6 & Drogues 2 to 6 \\
\hline Rhincalanus gigas (IV-VI) & 184.8 & 95.6 & 109.5 & - \\
\hline Calanus propinquus (V-VI) & 945.7 & 401.6 & 395.9 & - \\
\hline Calanoides acutus (III-IV) & 125.9 & 240.4 & 490.7 & - \\
\hline Metridia gerlachei (IV-VI) & 193.0 & 66.1 & 93.2 & - \\
\hline Clausocalanus spp. & - & - & - & 265.2 \\
\hline Ctenocalanus spp. & - & - & - & 152.0 \\
\hline Oithona spp. & - & - & - & 31.9 \\
\hline Euphausia superba, juveniles & - & - & - & 507.8 \\
\hline E. superba, subadults/adults & - & - & - & 1889 \\
\hline Thysanoessa macrura, juveniles & - & - & - & 131.5 \\
\hline T. macrura, subadults & - & - & - & 216.1 \\
\hline T. macrura, adults & - & - & - & 665.9 \\
\hline Limacina spp. & 2204 & 2429 & 5980 & - \\
\hline Salpa thompsoni, $1-2.5 \mathrm{~cm}$ long & - & - & - & 1700 \\
\hline S. thompsoni, $2.5-5 \mathrm{~cm}$ long & - & - & - & 3300 \\
\hline S. thompsoni, $>5 \mathrm{~cm}$ long & - & - & - & 65000 \\
\hline
\end{tabular}


Table 6. Summary of metazoan grazing impact (mg pig. $\mathrm{m}^{-2}$ $\mathrm{d}^{-1}$ ) during the 1994/95 drogue study in the Lazarev Sea

\begin{tabular}{|c|c|c|c|}
\hline Groups & Drogue 2 & Drogue 4 & Drogue 6 \\
\hline Copepoda & 0.674 & 0.416 & 0.544 \\
\hline Euphausiidae & 0.008 & 0.012 & 0.029 \\
\hline Pteropoda & 0.004 & 0.004 & 0.016 \\
\hline Tunicata & 0.362 & 0.238 & 0.024 \\
\hline $\begin{array}{l}\text { Total grazing } \\
\left(\mathrm{mg} \text { pig. } \mathrm{m}^{-2} \mathrm{~d}^{-1}\right)\end{array}$ & 1.048 & 0.670 & 0.613 \\
\hline Chl a stock (mg m $\left.{ }^{-2}\right)$ & 76.75 & 116.35 & 103.03 \\
\hline Grazing impact (\%) & 1.4 & 0.6 & 0.6 \\
\hline $\begin{array}{l}\text { Total grazing } \\
\left(\mathrm{mg} \mathrm{C} \mathrm{m}^{-2} \mathrm{~d}^{-1}\right)\end{array}$ & 144.2 & 78.86 & 68.41 \\
\hline $\begin{array}{l}\text { Primary production } \\
\left(\mathrm{mg} \mathrm{C} \mathrm{m}^{-2} \mathrm{~d}^{-1}\right)\end{array}$ & 394.2 & 464.2 & 454.9 \\
\hline Grazing impact (\%) & 36.6 & 17.0 & 15.0 \\
\hline
\end{tabular}

respond to a loss between 0.6 and $1.4 \%$ of the total integrated chl a standing stock or between 15 and $37 \%$ of the daily primary production (Table 6). Among the grazers, copepods were the most important, utilising between 62.1 and $88.7 \% \mathrm{~d}^{-1}$ of total pigment ingested. Salp grazing was substantial ( 35\%) during Drogues 2 and 4 and significantly decreased (3.9\%) during Drogue 6 . The contribution of euphausiids and pteropods varied between $0.7-4.8$ and $0.4-2.6 \%$ respectively (Table 6).

\section{Impact of algal sinking and zooplankton herbivory on algal biomass and total POC flux}

To investigate the relationships among sedimenting pigment fluxes, water column algal biomass and total downward POC fluxes, the inputs of PPC and FPC in the traps were compared with the chl a biomass in the top $50 \mathrm{~m}$ layer and with the total downward POC flux found in the traps (Table 1). The potential FPC contribution from the most abundant taxa of zooplankton (Table 4) was also compared to the total downward POC flux.

Overall, the fraction of the chl a from the top $50 \mathrm{~m}$ layer that sedimented daily below the top $200 \mathrm{~m}$ was consistent throughout the drogue study and never exceeded $0.6 \%$ of total POC flux (Table 1). The proportion of chl a that reached the traps in the form of phaeopigments ranged between 0.3 and $0.9 \%$, with highest values recorded during Drogues 2 and 6 (Table 1). At $50 \mathrm{~m}$ depth, the PPC contribution to the total downward POC flux ranged from 19 to $70 \%$ during the experiment, with lowest and highest contribution observed during Drogues 7 and 2 respectively
(Table 1). At $200 \mathrm{~m}$, the PPC contribution to total POC flux varied between 30 and $57 \%$, with the highest level observed during Drogue 3. The contribution of FPC to the total downward POC flux was generally low $(\leq 2 \%)$, with the highest contribution $(<15 \%)$ observed during Drogue 2 at depth $200 \mathrm{~m}$ and Drogue 7 at all depths (Table 1). During Drogue 2, ca. $71 \%$ of total downward POC flux at $200 \mathrm{~m}$ depth could be explained by the potential flux of zooplankton FPC. The potential contribution of FPC flux to total POC flux at $200 \mathrm{~m}$ decreased to 31 and $18 \%$ during Drogues 4 and 6 respectively (Table 1 ).

\section{DISCUSSION}

Although the drogue was deployed with the aim of studying biochemical processes within a specific, gradually modifying water mass, it is evident that on Days 5 (Drogue 4) to 9 (Drogue 6), a subsurface intrusion of colder, more saline water may have occurred (Fig. 2). The intrusion coincided with a change in the direction and speed of the drogue drift, but did not dramatically affect the physico-chemical structure of the upper $300 \mathrm{~m}$ water column. There are, however, indications that this intrusion resulted in a change in the phytoplankton structure as the region of investigation was exposed to a similar but successionally more advanced algal assemblage (Pakhomov et al. 2001). Coupled with this was a change in the zooplankton density (Table 4). Therefore, precautions should be taken comparing the results from the water column and sediment traps because traps may have encountered areas with patchy distribution of both phytoplankton and zooplankton.

Overall POC and chl a vertical fluxes observed during the drogue study were in the range previously recorded in the spring/summer sediment trap studies from a variety of Antarctic ecosystems (e.g. Schnack 1985, von Bodungen et al. 1988, Bathmann et al. 1991, Karl et al. 1991). A notable exception was the study conducted in the Bransfield Strait, where the flux of up to $1400 \mathrm{mg} \mathrm{C} \mathrm{m}^{-2} \mathrm{~d}^{-1}$ was documented (von Bodungen et al. 1986). Considerable short-term variability in the downward biogenic flux was evident during the period of investigation (Table 1), which is consistent with studies conducted in other oceanic regions, reflecting complexity of processes in the upper water column (e.g. Welschmeyer et al. 1984, Corn et al. 1994, Sasaki et al. 1997, Nodder \& Alexander 1998, Pusceddu et al. 1999).

The vertical flux of both chl $a$ and POC decreased with depth with only a small fraction of intact phytoplankton reaching deeper waters. The proportion of phytoplankton sedimented out daily from the upper 
$20 \mathrm{~m}$ water column (data not shown) was equivalent to between 2 and $4 \%$ of the phytoplankton stock above the trap. The flux may have been overestimated, as growth of phytoplankton in the $20 \mathrm{~m}$ trap might have occurred. Indeed, little material $(<2 \%)$ escaped from the top $50 \mathrm{~m}$ water column and only $<0.5 \%$ of both chl $a$ and POC sedimented beyond the $200 \mathrm{~m}$ depth layer. The loss rates were therefore similar to those identified in other oceanic regions (e.g. Nöting \& von Bodungen 1989, Bathmann et al. 1991, Karl et al. 1991, Andreassen \& Wassmann 1998, Smith \& Dunbar 1998). Higher loss rates of chl a could be found in regions where the bulk of plant pigments was either found in FPC of large metazoans (Schnack 1985, Thibault et al. 1999) or represented by sinking of phytoplankton in the ice zone (Sasaki \& Hoshiai 1986, Smith \& Nelson 1986, Tremblay et al. 1989, Handa et al. 1992).

Coupled with low chl a losses, no extensive phytoplankton recycling occurred within the euphotic zone during the drogue study. This was supported by the similar loss rates of phytoplankton (as chl a) and total POC at $50 \mathrm{~m}$ depth (Table 1). In contrast with the upper $50 \mathrm{~m}$ water column, at $200 \mathrm{~m}$ depth the loss rates of POC were 1.5- to 2-fold higher than phytoplankton loss rates (Table 1), pointing to the substantial recycling of phytoplankton within the 50 to 200 m layer. Furthermore, the chl a:phaeopigment ratio in the top 60 to $70 \mathrm{~m}$ was generally $>1$, indicating that sinking consisted mainly of phytoplankton rather than more decomposed material. This pattern changed below the $70 \mathrm{~m}$ depth, providing evidence for zooplankton grazing within the 70 to $200 \mathrm{~m}$ layer. The amount of POC, which disappeared between 50 and $200 \mathrm{~m}$, ranged from 13 to $25 \%$ of the total primary production (average $20.1 \pm 5.5 \%$, Table 1 ) and may crudely represent the grazing impact of metazoan zooplankton. These values are very similar to our herbivorous zooplankton grazing estimates obtained using the gut fluorescence method (range 15 to $37 \%$, average $22.9 \pm 11.9 \%$, Table 6).

PPC comprised 15 to $70 \%$ of the vertical POC flux throughout the entire 0 to $200 \mathrm{~m}$ water column, confirming that identifiable phytoplankton cells represented on average $1 / 3$ of the total biogenic flux. Contribution of FPC was generally $<3 \%$ of total POC and never exceeded $16 \%$ of the total downward POC flux. The C:chl a ratios generally exceeded 180 in the entire water column, suggesting the presence of a substantial pool of detritus in the euphotic zone. Our calculations indicate that the unaccounted POC fraction (POCPPC-FPC) in the upper $50 \mathrm{~m}$ (Table 1), tentatively representing the detritus pool, varied between 26 and $72 \%$ (mean $55 \pm 17 \%$ ). This is in the same range (16 to $64 \%$ ) observed in Norwegian fjords (Reigstad et al. 2000). There are, however, possible sources of over- estimation of the detritus contribution, as a major part of detritus pool could include broken faecal pellets and/or bacterial aggregates and protozoans.

The potential contribution of faecal pellets at $200 \mathrm{~m}$ depth, calculated from zooplankton ingestion rates assuming $70 \%$ assimilation efficiency, should be substantially higher, ranging from 18 to $71 \%$ of total POC flux (Table 1). Simple calculations demonstrate that between 87 and $99 \%$ of faecal pellets were remineralized in the upper $200 \mathrm{~m}$ layer. These rates are similar to values reported in the literature (e.g. Viitasalo et al. 1999), implying that faecal pellets are either extensively broken down and/or efficiently recycled, probably through coprophagy, coprorhexy and coprochaly (Fortier et al. 1994, Bathmann 1998). The latter situation normally occurs under conditions of low food concentration and high zooplankton densities, particularly cyclopoids (Fortier et al. 1994, Bathmann 1998). Unfortunately, densities of small calanoids and cyclopoids during this study were likely substantially underestimated due to the sampling gear employed. More important for the downward flux could be faecal pellets of large metazoans, such as the tunicate Salpa thompsoni (Perissinotto \& Pakhomov 1998a,b). However, salp faecal pellets were never encountered in sediment traps during the drogue study. This points to the inefficiency of small sediment traps in collecting rare faecal pellets of large metazoans. Nevertheless, natural breakage of pellets and/or extensive coprophagy on them in the water column cannot be discounted.

Interestingly, according to sediment trap data, the grazer-mediated flux increased by at least one order of magnitude between Drogues 3 and 7 , probably demonstrating an increasing role of zooplankton grazing in the carbon sink. This, however, was in contradiction to actual measurements using the gut fluorescence method, which showed a decrease in grazing impact during the course of the drogue study (Table 6). The decrease in zooplankton grazing coincided with a significant drop in tunicate abundance and grazing impact, while copepod grazing remained stable. An increase in faecal pellet contribution to total POC flux may therefore reflect better feeding conditions for copepods, which probably allowed them to switch from coprophagy to a mainly herbivorous feeding mode.

The physico-chemical environment during the period of the drogue study was characterized by the presence of a well-developed pycnocline at $\sim 30 \mathrm{~m}$ depth, high nutrient concentrations (M. Lucas unpubl.) and favorable light conditions. The area recently became ice free and therefore the development of a phytoplankton bloom was anticipated (Smith \& Sakshaug 1990, Sakshaug et al. 1991, Goosse \& Hecq 1994). Sediment trap data show that between 5 and $27 \%$ of pri- 


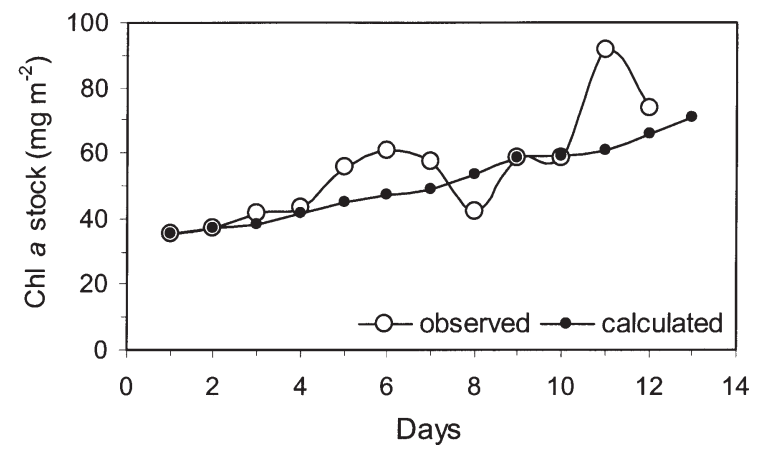

Fig. 11. Measured and predicted chl a standing stock in the top 0 to $50 \mathrm{~m}$ water layer. Predicted chl a stock for Day 2 was calculated using daily budget approach as follows: chl a stock for Day 1 + daily primary production - phytoplankton cell lysis (assumed as $8 \% \mathrm{~d}^{-1}$ after Murphy et al. 1998) - pigment flux at $50 \mathrm{~m}$ sediment trap (Table 1)-microzooplankton grazing (ca. $0.8 \mathrm{mg}$ pig. $\mathrm{m}^{-2} \mathrm{~d}^{-1}$, after Froneman et al. 1996) - metazoan grazing (Table 5)

mary production left the euphotic zone in the form of PPC and $\leq 42 \%$ of primary production escaped this layer in the form of POC (Table 1). This allowed an accumulation of phytoplankton (see Fig. 4B) in the upper surface layers during the drogue study. Predictions (for the following day, see legend of Fig. 11) for the chl a stock build-up in the top $50 \mathrm{~m}$ layer described the measured chl a stock dynamics well, suggesting that our measurements are accurate and assumptions valid (Fig. 11). The duration of the drogue study appeared to be insufficient for the proper development of a phytoplankton bloom (Moline et al. 1997). This is supported by chl a concentrations of $>2.5 \mathrm{mg} \mathrm{m}^{-3}$ reported during the post-drogue grid survey (Perissinotto \& Pakhomov 1998a) and during previous surveys in the same area (Laubscher et al. 1993, Perissinotto et al. 1997).

Grid surveys conducted in the region of drogue deployment prior and immediately after the drogue experiment described a clear shift in the size composition of phytoplankton assemblage from a community dominated by nano- and picophytoplankton to one domi- nated by microphytoplankton (Froneman et al. 1997). Our findings show that this shift occurred largely during the drogue study (Fig. 4A). Zooplankton abundance and community grazing impact increased during the same period (Table 7). Although no sediment traps were deployed, it has been postulated that grazer-mediated downward carbon flux was twice as efficient during the pre-drogue survey (Froneman et al. 1997). The results of the drogue study clearly demonstrated that despite increase in zooplankton grazing (Table 7) and FPC flux (Table 1), phytoplankton sinking dominated overall flux during the onset of the MIZ bloom (Table 1). The findings of the drogue study thus point out that estimates of vertical carbon flux obtained from the gut fluorescence technique alone might be misleading.

\section{CONCLUSION}

Major export events in the seasonally ice-covered waters include the release and sedimentation of ice algae during the time of ice melt (e.g. Sasaki \& Hoshiai 1986, Matsuda et al. 1987, Tremblay et al. 1989), massive sinking of ice-edge blooms (e.g. Smith \& Nelson 1986, Wilson et al. 1986, Bathmann et al. 1991), and sedimentation of algae from the spring-summer phytoplankton bloom (e.g. Schnack et al. 1985, Sasaki \& Hoshiai 1986, von Bodungen et al. 1986, Handa et al. 1992). It is generally accepted that outside these periods, the sinking of faecal material largely dominates the downward vertical flux of POC (Schnack 1985, von Bodungen et al. 1988, Bathmann et al. 1991, Karl et al. 1991, Cadée 1992). The results of the drogue study show that the contribution of grazing-mediated POC flux was insignificant during the onset of the MIZ bloom. Apparently, large meso- and macrozooplankton densities and feeding activities were insufficient to exert either positive (via faecal pellets) or negative (via reducing suspended phytoplankton concentration) effects on sedimentation (Sarnelle 1999). As a consequence of the classical mismatch between phytoplank-

Table 7. Comparison of abundance and grazing impact of most important herbivorous zooplankton species during pre-drogue, drogue and post-drogue surveys in the top $300 \mathrm{~m}$ water column. Pre- and post-drogue data were extracted from Froneman et al. (1997). Underlined values are significantly different ( $p$-values are provided) from each other (1-way ANOVA with a post-hoc comparisons using Tukey's test for unequal n)

\begin{tabular}{|c|c|c|c|c|}
\hline \multirow[t]{2}{*}{ Period } & \multicolumn{2}{|c|}{ Abundance (ind. $\mathrm{m}^{-3}$ ) } & \multicolumn{2}{|c|}{ Grazing impact (mg pig. $\mathrm{m}^{-2} \mathrm{~d}^{-1}$ ) } \\
\hline & Range & Mean $( \pm \mathrm{SD})$ & Range & Mean $( \pm \mathrm{SD})$ \\
\hline Pre-drogue $(\mathrm{n}=8)$ & $2.5-12.5$ & $\underline{5.5 \pm 3.3}$ & $0.07-0.61$ & $\underline{0.34 \pm 0.18}$ \\
\hline Drogue $(\mathrm{n}=3)$ & $12.1-19.8$ & $14.7 \pm 4.4$ & $0.61-1.05$ & $0.78 \pm 0.24$ \\
\hline Post-drogue $(\mathrm{n}=4)$ & $5.5-16.4$ & $11.0 \pm 4.9$ & $0.66-2.15$ & $\underline{1.19 \pm 0.66}$ \\
\hline $\mathrm{p}$-value & \multicolumn{2}{|c|}{0.0353} & \multicolumn{2}{|c|}{0.0208} \\
\hline
\end{tabular}


ton production and zooplankton grazing in the MIZ, the most important mechanism of the downward POC flux was algal sinking. This scenario may be true during the pre-bloom period (sinking of ice algae) and is likely to persist during the post-bloom period as well (massive sinking of ice-edge blooms). Finally, the results of this study clearly demonstrate the importance of the upper layer for the vertical flux regulation in the Antarctic MIZ. This is similar to processes described in the MIZ of the Barents Sea (Andreassen \& Wassmann 1998), where the bulk of the organic carbon was retained and probably re-mineralized through microbial food and classical webs in the upper euphotic and aphotic zones. This calls for a re-evaluation of the importance of micro- versus mesozooplankton grazing in the dynamics of the Antarctic marine ecosystem.

Acknowledgements. We are grateful to the South African Department of Environmental Affairs and Tourism (Pretoria), Rhodes University (Grahamstown), Norwegian College of Fisheries Science (Troms $\varnothing$ ), P. P. Shirshov Institute of Oceanology (Moscow) and University of Fort Hare (Alice, South Africa) for providing financial support and facilities, which allowed the completion of this study. This research was partly fulfilled within a framework and owing to the financial support of the sub-programme 'Studies and investigations of the Antarctic', FGP 'World Ocean', Project \#16 'Conducting of the multi-disciplinary study of the Antarctic biota'. We would like to thank many of our colleagues for providing samples for analysis and giving us the opportunity to use unpubl. data. We are grateful to V. Meaton, F. Tonning and S. Øygarden for their dedicated work in the field and laboratory. We are also very thankful to the Chief Scientist of the SODOFS cruise, the officers and crew of the MV 'SA Agulhas' for their invaluable assistance at sea.

\section{LITERATURE CITED}

Andreassen IJ, Wassmann P (1998) Vertical flux of phytoplankton and particulate biogenic matter in the marginal ice zone of the Barents Sea in May 1993. Mar Ecol Prog Ser 170:1-14

Baars MA, Helling GR (1985) Methodological problems in the measurements of phytoplankton ingestion rate by gut fluorescence. Hydrobiol Bull 19:81-88

Bathmann U (1998) Ecology and biochemistry in the Atlantic sector of the Southern Ocean during austral spring: the first JGOFS expedition aboard PV 'Polarstern'. J Mar Syst 17:77-85

Bathmann U, Fischer G, Müller PJ, Gerdes D (1991) Shortterm variations in particulate matter sedimentation off Kapp Norvegia, Weddell Sea, Antarctica: relation to water mass advection, ice cover, plankton biomass and feeding activity. Polar Biol 11:185-195

Bender ML, Ducklow HW, Kiddon J, Marra J, Martin JH (1992) The carbon balance during the 1989 spring bloom in the North Atlantic Ocean at $47^{\circ} \mathrm{N} 20^{\circ} \mathrm{W}$. Deep-Sea Res 39:1707-1725

Booth BC, Lewin J, Postel JR (1993) Temporal variations in the structure of autotrophic and heterotrophic communities in the subarctic Pacific. Prog Oceanogr 32:57-99

Boyd PW, Harrison PJ (1999) Phytoplankton dynamics in the NE subarctic Pacific. Deep-Sea Res II 46:2405-2432

Cadée GC (1992) Organic carbon in the upper layer and its sedimentation during the ice-retreat period in the ScotiaWeddell Sea, 1988. Polar Biol 12:253-259

Cadée GC, Gonzalez H, Schnack-Schiel SB (1992) Krill diet affects faecal string settling. Polar Biol 12:75-80

Carlson CA, Ducklow HW, Hansell DA, Smith WO (1998) Organic carbon partitioning during phytoplankton blooms in the Ross Sea polynya and the Sargasso Sea. Limnol Oceanogr 43:375-386

Comiso JC, Zwally HJ (1984) Concentration gradients and growth/decay characteristics of the seasonal sea ice cover. J Geophys Res 89:8081-8103

Conover RJ, Durvasula R, Roy S, Wang R (1986) Probable loss of chlorophyll-derived pigments during passage through the gut of zooplankton and some of the consequences. Limnol Oceanogr 31:878-887

Corn M, Belviso S, Nival P, Vigot A, Buat-Menard P (1994) Downward flux of particulate dimethylsulfoniopropionate (DMSP) in areas of the tropical open ocean. Oceanol Acta 17:233-236

Downs JN, Lorenzen CJ (1985) Carbon:phaeopigment ratios of zooplankton fecal pellets as an index of herbivorous feeding. Limnol Oceanogr 30:1024-1036

Edler L (ed) (1979) Recommendations for marine biological studies in the Baltic Sea-phytoplankton and chlorophyll. The Baltic Marine Biologists, Vol 5. Opulus Press, Uppsala, p 1-38

Fasham MJR, Boyd PW, Savidge G (1999) Modeling the relative contributions of autotrophs and heterotrophs to carbon flow at a Lagrangian JGOFS station in the Northeast Atlantic: the importance of DOC. Limnol Oceanogr 44:80-94

Fortier L, LeFevre J, Legendre L (1994) Export of biogenic carbon to fish and to the deep ocean: the role of large planctonic microphages. J Plankton Res 7:809-839

Froneman PW, Perissinotto R, McQuaid CD (1996) Dynamics of microplankton communities at the ice-edge zone of the Lazarev Sea during a summer drogue study. J Plankton Res 18:1455-1470

Froneman PW, Pakhomov EA, Perissinotto R, Laubscher RK, McQuaid CD (1997) Dynamics of the plankton communities during seasonal ice melt in the Lazarev Sea in austral summer 1994-1995. Mar Ecol Prog Ser 149:201-214

Goosse H, Hecq JH (1994) Modelling the ice-ocean-plankton interactions in the Southern Ocean. J Mar Syst 5:471-484

Handa N, Nakatsuka T, Fukuchi M, Hattori H, Hoshiai T (1992) Vertical fluxes and ecological significance of organic materials during the phytoplankton bloom during austral summer in Breid Bay, Antarctica. Mar Biol 112: $469-478$

JGOFS (1990) Core measurement protocols: reports of the core measurement working groups. Report No. 6, Scientific Committee on Oceanic Research, Carqueiranne

Karl DM, Tilbrook BD, Tien G (1991) Seasonal coupling of organic matter production and particle flux in the western Bransfield Strait, Antarctica Deep-Sea Res 38:1097-1126

Knox GA (1994) The biology of the Southern Ocean. Cambridge University Press, Cambridge

Laubscher RK, Perissinotto R, McQuaid CD (1993) Phytoplankton production and biomass at frontal zones in the Atlantic sector of the Southern Ocean. Polar Biol 13: 471-481

Mackas D, Bohrer R (1976) Fluorescence analysis of zooplankton gut contents and an investigation of diel feeding patterns. J Exp Mar Biol Ecol 25:77-85 
Makarov RR, Sysoeva NB (1983) Biological condition and distribution of Euphausia superba Dana in the Lazarev Sea and ajacent waters. In: Lubimova TG, Makarov RR, Kamenskaya EA (eds) Antarctic krill. Peculiarities of distribution and environment. Legkaja i Pischevaja Promyshlennost, Moscow, p 110-117

Matsuda O, Ishikawa S, Kawaguchi K (1987) Seasonal variation of downward flux of particulate organic matter under the Antarctic fast ice. Proc NIPR Symp Polar Biol 1:23-34

Moline MA, Prezelin BB, Schofield O, Smith RC (1997) Temporal dynamics of coastal Antarctic phytoplankton: environmental driving forces and impact of a 1991/92 summer diatom bloom on the nutrient regimes. In: Battaglia B, Valencia J, Walton SWH (eds) Antarctic communities. Species, structure and survival. Cambridge University Press, Cambridge, p 67-72

Murphy EJ, Boyd PW, Leakey RJG, Atkinson A and 9 others (1998) Carbon flux in the ice-ocean-plankton systems of the Bellingshausen Sea during a period of ice retreat. J Mar Syst 17:207-227

Nodder SD, Alexander BL (1998) Sources of variability in geographical and seasonal differences in particulate fluxes from short-term sediment trap deployments, east of New Zealand. Deep-Sea Res I 45:1739-1764

Nöting EM, von Bodungen B (1989) Occurrence and vertical flux of FPC of probably protozoan origin in the southeastern Weddell Sea (Antarctica). Mar Ecol Prog Ser 56:281-289

Pakhomov EA, Ratkova T, Froneman PW, Wassmann P (2001) Phytoplankton dynamics at the ice-edge zone of the Lazarev Sea (Southern Ocean) during the austral summer 1994/95 drogue study. Polar Biol 24:422-431

Parsons TR, Maita Y, Lalli CM (1984) A manual of chemical and biological methods for seawater analysis. Pergamon Press, Oxford

Peinert R, von Bodungen B, Smetacek VS (1989) Food web structure and loss rate. In: Berger $\mathrm{WH}$, Smetacek VS, Wefer G (eds) Productivity of the Ocean: present and past. Wiley, New York, p 35-48

Perissinotto R (1992) Mesozooplankton size selectivity and grazing impact on the phytoplankton community of the Prince Edward Archipelago (Southern Ocean). Mar Ecol Prog Ser 79:243-258

Perissinotto R, Pakhomov EA (1996) Gut evacuation rates and pigment destruction in the Antarctic krill Euphausia superba. Mar Biol 125:47-54

Perissinotto R, Pakhomov EA (1998a) The trophic role of the tunicate Salpa thompsoni in the Antarctic marine ecosystem. J Mar Syst 17:361-374

Perissinotto R, Pakhomov EA (1998b) Contribution of salps to carbon flux of marginal ice zone of the Lazarev Sea, Southern Ocean. Mar Biol 131:25-32

Perissinotto R, Pakhomov EA, McQuaid CD, Froneman PW (1997) In situ grazing rates and daily ration of Antarctic krill Euphausia superba feeding on phytoplankton at the Antarctic Polar Front and the Marginal Ice Zone. Mar Ecol Prog Ser 160:77-91

Pusceddu A, Cattaneo-Vietti R, Albertelli G, Fabiano M (1999) Origin, biochemical composition and vertical flux of particulate organic carbon under the pack ice in Terra Nova Bay (Ross Sea, Antarctica) during late summer 1995. Polar Biol 22:124-132

Reigstad M, Wassmann P, Ratkova T, Arashkevich E, Pasternak A, Øygarden S (2000) Comparison of the springtime vertical export of biogenic matter in 3 northern Norwegian fjords. Mar Ecol Prog Ser 201:73-89

Rousseau V, Mathot S, Lancelot C (1990) Calculating carbon biovolume of Phaeocystis sp. from microscopic observa- tions. Mar Biol 107:305-314

Sakshaug E, Slagstad D, Holm-Hansen O (1991) Factors controlling the development of phytoplankton blooms in the Antarctic Ocean-a mathematical model. Mar Chem 35: $259-271$

Sarnelle O (1999) Zooplankton effects on vertical particle flux: testable models and experimental results. Limnol Oceanogr 44:357-370

Sasaki H, Hoshiai T (1986) Sedimentation of microalgae under the Antarctic fast ice in summer. Mem Natl Inst Polar Res 40:45-55

Sasaki H, Suzuki H, Takayama M, Suzuki K, Handa N, Kudoh S, Fukuchi M (1997) Sporadic increase of particle sedimentation at the ice edge of the Antarctic Ocean during the austral summer 1994-1995. Proc NIPR Symp Polar Biol 10:50-55

Savidge G, Priddle J, Gilpin LC, Bathmann U and 6 others (1996) An assessment of the role of the marginal ice zone in the carbon cycle of the Southern Ocean. Antarct Sci 8: $349-358$

Semina HJ (1978) Treatment of an aliquot sample. In: Sournia A (ed) Phytoplankton manual. UNESCO, Paris, p 181

Schnack SB (1985) A note on the sedimentation of particulate matter in Antarctic waters during summer. Meeresforschung 30:306-315

Schnack SB, Smetacek V, von Bodungen B, Stegmann P (1985) Utilization of phytoplankton by copepods in Antarctic waters during spring. In: Gray JS, Christiansen ME (eds) Marine biology of Polar regions. Effects of stress on marine organisms. John Wiley \& Sons, Chichester, p 65-81

Smayda TJ (1978) From phytoplankters to biovolume. In: Sournia A (ed) Phytoplankton manual. UNESCO, Paris, p 273-279

Smetacek V, Scharek R, Nöting EM (1990) Seasonal and regional variation in the pelagial and its relationship to the life history cycle of krill. In: Kerry KR, Hempel G (eds) Antarctic ecosystems. Ecological change and conservation. Springer-Verlag, Berlin, p 103-114

Smith WO Jr, Dunbar RB (1998) The relationship between new production and vertical flux on the Ross Sea continental shelf. J Mar Syst 17:445-457

Smith WO Jr, Nelson DM (1985) Phytoplankton biomass near a receding ice-edge in the Ross Sea. In: Siegfried WR, Condy PR, Laws RW (eds) Antarctic nutrient cycles and food webs. Springer-Verlag, Berlin, p 70-75

Smith WO Jr, Nelson DM (1986) Importance of ice edge phytoplankton production in the Southern Ocean. BioScience 36:251-257

Smith WO Jr, Sakshaug E (1990) Polar phytoplankton. In: Smith WO (ed) Polar oceanography. Part A: physical science. Part B: chemistry, biology, geology. Academic Press, San Diego, p 477-526

Strathmann (1967) Estimating the organic carbon content of phytoplankton from cell volume or plasma volume. Limnol Oceanogr 12:411-418

Strickland JDH, Parsons TR (1968) A practical handbook of seawater analysis. Bull Fish Res Board Can 167:1-311

Thibault D, Roy S, Wong CS, Bishop JK (1999) The downward flux of biogenic material in the NE subarctic Pacific: importance of algal sinking and mesozooplankton herbivory. Deep-Sea Res II 46:2669-2697

Tremblay C, Runge JA, Legendre L (1989) Grazing and sedimentation of ice algae during and immediately after a bloom at the ice-water interface. Mar Ecol Prog Ser 56: 291-300

Viitasalo M, Rosenberg M, Heiskanen AS, Koski M (1999) 
Sedimentation of copepod fecal material in the coastal northern Baltic Sea: where did all the pellets go? Limnol Oceanogr 44:1388-1399

von Bodungen B, Smetacek V, Tilzer MM, Zeitzschel B (1986) Primary production and sedimentation during spring in the Antarctic Peninsula region. Deep-Sea Res 33:177-194 von Bodungen B, Nöting EM, Sui Q (1988) New production of phytoplankton and sedimentation during summer 1985 in the South Eastern Weddell Sea. Comp Biochem Physiol 90B: $457-487$

Wefer G (1989) Particle flux in the ocean: effects of episodic

Editorial responsibility: Otto Kinne (Editor), Oldendorf/Luhe, Germany production. In: Berger WH, Smetacek V, Wefer F (eds) Productivity of the ocean: present and past. Wiley \& Sons, New York, p 139-154

Welschmeyer NA, Copping AE, Vernet M, Lorenzen CJ (1984) Diel fluctuation in zooplankton grazing rate as determination from the downward vertical flux of pheopigments. Mar Biol 83:263-270

Wilson DL, Smith WO, Nelson D (1986) Phytoplankton bloom dynamics in the western Ross Sea ice edge. I. Primary productivity and species-specific production. Deep-Sea Res 33:1375-1387

Submitted: December 18, 2000 Accepted: November 13, 2001 Proofs received from author(s): April 16, 2002 